\title{
Modulation of the In Vitro Candidacidal Activity of Human Neutrophil Defensins by Target Cell Metabolism and Divalent Cations
}

\author{
Robert I. Lehrer, "* Tomas Ganz,"\$ Dorothy Szklarek," and Michael E. Selsted" \\ Departments of Medicine* and Pathology," and Will Rogers Institute Pulmonary Research Laboratory, ${ }^{\S}$ UCLA School of Medicine, \\ University of California, Los Angeles, Los Angeles, California 90024; and ${ }^{\ddagger}$ Department of Medicine, \\ Veterans Administration Medical Center, West Los Angeles, California 90073
}

\begin{abstract}
We tested the in vitro susceptibility of Candida albicans to three defensins from human neutrophilic granulocytes (HNP-1, 2, and 3), a homologous defensin from rabbit leukocytes (NP-1), and four unrelated cationic peptides. Although the primary amino acid sequences of HNP-1, 2, and 3 are identical except for a single amino-terminal amino acid alteration, HNP-1 and HNP-2 killed $C$. albicans but HNP-3 did not. $C$. albicans blastoconidia were protected from HNP-1 when incubations were performed in the absence of oxygen or in the presence of inhibitors that blocked both of its mitochondrial respiratory pathways. Neither anaerobiosis nor mitochondrial inhibitors substantially protected $C$. albicans exposed to NP-1, poly-L-arginine, poly-L-lysine, or mellitin. Human neutrophilic granulocyte defensin-mediated candidacidal activity was inhibited by both $\mathrm{Mg}^{2+}$ and $\mathrm{Ca}^{2+}$, and was unaffected by $\mathrm{Fe}^{2+}$. In contrast, $\mathrm{Fe}^{2+}$ inhibited the candidacidal activity of NP-1 and all of the model cationic peptides, whereas $\mathrm{Mg}^{2+}$ inhibited none of them. These data demonstrate that susceptibility of $\boldsymbol{C}$. albicans to human defensins depends both on the ionic environment and on the metabolic state of the target cell. The latter finding suggests that leukocyte-mediated microbicidal mechanisms may manifest oxygen dependence for reasons unrelated to the production of reactive oxygen intermediates by the leukocyte.
\end{abstract}

\section{Introduction}

Defensins are small (mol wt 3,500-4,000), variably cationic, cystine-rich antimicrobial peptides that are major constituents of PMN azurophil granules. They are active in vitro against gram-positive and gram-negative bacteria, certain fungi, and enveloped viruses (1-7). By virtue of their net positive charges at physiological $\mathrm{pH}$, defensins may be considered to be "cationic peptides."

Although the primary structures of the human defensins are established (1), their antimicrobial mechanisms are not known. To delineate the antifungal properties of human defensins, we tested human PMN defensins against blastoconidia of $C$. albicans. Certain metabolic inhibitors and divalent cat-

Address correspondence and reprint requests to Dr. Lehrer, Department of Medicine, UCLA School of Medicine, Los Angeles, CA 90024.

Received for publication 27 April 1987 and in revised form 8 December 1987.

J. Clin. Invest.

(c) The American Society for Clinical Investigation, Inc.

0021-9738/88/06/1829/07 \$2.00

Volume 81, June 1988, 1829-1835 ions showed dissimilar effects on the candidacidal activities of the most potent human (HNP-1) and rabbit (NP-1) defensins $(5,6)$. By comparing both of these defensins to selected natural or synthetic "model" cationic peptides, we identified several properties that appear unique to the human PMN defensins. This article describes our observations.

\section{Methods}

Proteins and peptides. Normal human neutrophilic granulocytes were obtained by leukopheresis and their defensins were purified as previously described (3). NP-1 was purified from rabbit peritoneal granulocytes (5). Salmon sperm protamine (free base), mellitin, poly-L-lysine hydrobromide (average mol wt 17,000) and poly-L-arginine hydrochloride (average mol wt 40,000) were obtained from Sigma Chemical Co., St. Louis, MO and used without further purification. Certain properties of these proteins and peptides are summarized in Table I.

Candidacidal testing. Susceptibility of $C$. albicans strain 820 to defensins and other cationic peptides was tested as previously described (6). In brief, $10^{6} \mathrm{CFU} / \mathrm{ml}$ of washed C. albicans blastoconidia from an 18-h broth culture were incubated at $37^{\circ} \mathrm{C}$ for up to $4 \mathrm{~h}$ with specified concentrations of the peptides in $10 \mathrm{mM}$ Na phosphate buffer (pH 7.4, ionic strength $1.36 \mathrm{mS}$ ). Colony counts were obtained, in duplicate, from each of three serial, 10-fold-diluted samples. Experimental results were confirmed on at least three separate occasions, unless otherwise noted.

Oxygen consumption. The effect of various metabolic inhibitors was tested in a model K-1C Oxygraph (Gilson Medical Electronics, Inc., Middleton, WI) fitted with dual Clark-YSI electrodes (Yellow Springs Instrument Co., Yellow Springs, $\mathrm{OH}$ ) in thermostatted, stirred chambers ( $\mathrm{vol} 1.2 \mathrm{ml})$ that were maintained at $37^{\circ} \mathrm{C}$.

Anaerobic experiments. Anaerobic experiments were performed in a gloveless anaerobic chamber (Anaerobe Systems, Santa Clara, CA) generously made available to us by Prof. S. Finegold and Dr. H. Wexler (Veterans Administration Medical Center, West Los Angeles, CA). C. albicans was grown aerobically for $18 \mathrm{~h}$ in Sabouraud's-2\% dextrose broth, as in our aerobic experiments, washed twice aerobically

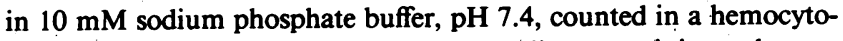
meter, and again centrifuged. The wet pellet, containing a known number of CFU, was transferred via a special exchange passage into the anaerobic chamber, wherein it was taken up in $5 \mathrm{ml}$ of anaerobic buffer, centrifuged, and resuspended in anaerobic buffer. All media within the chamber had been equilibrated with an atmosphere of $80 \%$ nitrogen, $10 \% \mathrm{CO}_{2}$, and $10 \% \mathrm{H}_{2}$ for $24-40 \mathrm{~h}$, and all procedures (primary incubation, diluting, plating, secondary incubation) were performed anaerobically through tightly sealed access ports. Because C. albicans colonies developed quite slowly under anaerobic conditions, in most instances the petri dishes were transferred after $42 \mathrm{~h}$ of anaerobic incubation to an aerobic incubator where they were additionally incubated for $24-48 \mathrm{~h}$ before CFU were counied.

\section{Results}

Activity of defensins against $C$. albicans. Despite possessing similar primary structures, the human neutrophil's defensins differed in relative potency against $C$. albicans. Fig. 1 depicts 
Table I. Selected Properties of Cationic Peptides

\begin{tabular}{lcccccr}
\hline Peptide & $\begin{array}{c}\text { All } \\
\text { amino } \\
\text { acids }\end{array}$ & $\begin{array}{c}\text { Arginine } \\
\text { (R) }\end{array}$ & $\begin{array}{c}\text { Lysine } \\
\text { (K) }\end{array}$ & $\begin{array}{c}\text { Glutamic } \\
\text { acid } \\
\text { (E) }\end{array}$ & $\begin{array}{c}\text { Aspartic } \\
\text { acid } \\
\text { (D) }\end{array}$ & Net \\
\hline HNP-1 & 30 & 4 & 0 & 1 & 0 & +3 \\
NP-1 & 33 & 10 & 0 & 1 & 0 & +9 \\
Mellitin & 26 & 2 & 3 & 0 & 0 & +5 \\
Protamine & 33 & 21 & 0 & 0 & 0 & +21 \\
& & & & & & \\
\hline
\end{tabular}

"Net" signifies net molecular charge, calculated as $[(R+K)-(E$

$+D)$ ]. Sources used to construct this table were HNP-1 (1), NP-1 (7), mellitin (38), and protamine (39).

the kinetics of the candidacidal activity induced by exposing organisms to $50 \mu \mathrm{g} / \mathrm{ml}$ of each of the three human defensins in nutrient-free, dilute phosphate buffer. Note that HNP-1 was more effective than HNP-2, and also that HNP-3 exerted almost no candidacidal activity. Because virtually all of the candidacidal effects of the human defensins had occurred after $2 \mathrm{~h}$ of incubation, this time period was most often selected for subsequent studies.

Fig. 2 demonstrates that NP-1, the most potent candidacidal defensin of rabbit granulocytes and alveolar macrophages $(5,6)$, was $\sim 10-20$ times more active than HNP-1 against $C$. albicans on a concentration basis. The minimal defensin concentrations required for candidacidal activity under these conditions were $\sim 1 \mu \mathrm{g} / \mathrm{ml}$ for NP-1 and $10 \mu \mathrm{g} / \mathrm{ml}$ for HNP-1. Exposure of the organisms to defensin concentrations above threshhold levels resulted in a mean decrease in $\log _{10} \mathrm{CFU} / \mathrm{ml}$ that was roughly proportional to the $\log _{10}$ of the defensin concentration.

Inhibition of mitochondrial metabolism. C. albicans blastoconidia prepared for our experiments were metabolically active, as evidenced by their substantial rate of oxygen consumption, even in the absence of exogenous nutrients. We confirmed published reports that $C$. albicans has a branched respiratory chain $(8,9)$ that includes an alternative, cryptic limb, which although insensitive to cyanide and antimycin A, is potently inhibited by salicylhydroxamic acid (SHAM) ${ }^{1}$ or high (e.g., $5 \mathrm{mM}$ ) concentrations of azide (9). Consequently, sequential or concomitant addition of $3 \mathrm{mM}$ SHAM and 1 $\times 10^{-6} \mathrm{M}$ antimycin A completely blocked $C$. albicans respiration and addition of $5 \mathrm{mM}$ azide caused substantial respiratory inhibition that was rendered complete by subsequent addition of antimycin A. In contrast, the transient block in $\mathrm{O}_{2}$ consumption caused by cyanide was followed by the resumption of respiration via the alternative pathway. Several of these features are illustrated in Fig. 3.

Effects of mitochondrial inhibitors and anerobic conditions on HNP-1. Fig. 4 demonstrates the effects of sodium chloride, sodium cyanide, and sodium azide on the ability of HNP-1 to kill C. albicans. Although sodium cyanide was no more inhibitory than an equivalent concentration of sodium chloride, 5

1. Abbreviations used in this paper: $\mathrm{CCCP}$, carbonyl cyanide $m$-chlorophenylhydrazone; SHAM, salicyl hydroxamic acid.

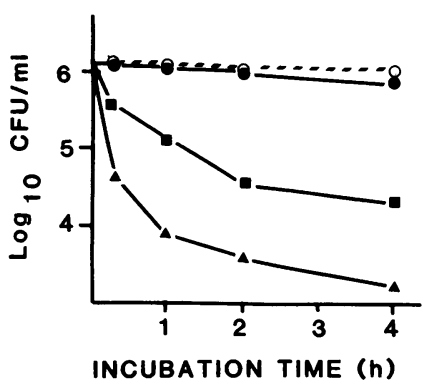

Figure 1. Activity of purified human defensins against $C$. albicans. Blastoconidia were incubated with $50 \mu \mathrm{g} / \mathrm{ml}$ of HNP-1 ( $\triangle$ ), HNP-2 (घ), or HNP-3 (๑) for $4 \mathrm{~h}$ at $37^{\circ} \mathrm{C}$ in $10 \mathrm{mM}$ sodium phosphate buffer, pH 7.4. Aliquots were removed at intervals, serially diluted and plated on Sabouraud's-2\% dextrose agar. Defensin-free control (O).

mM sodium azide completely protected the target cells from HNP-1. Because $5 \mathrm{mM}$ azide inhibits both the classical and alternative pathways of mitochondrial respiration, whereas cyanide blocks only the classical pathway, we decided to test the possibility that the selective inhibitory effect of azide implied a role for mitochondrial metabolism in sensitizing $C$. albicans to human defensins.

Like cyanide, antimycin A blocks only the conventional mitochondrial pathway. By combining it with SHAM, which blocks only the alternative one, it is possible to completely inhibit oxygen consumption by C. albicans (Fig. 3). Although antimycin $\mathrm{A}$ alone provided little protection to $C$. albicans exposed to HNP-1 and SHAM was only moderately protective, the combination of antimycin A and SHAM provided substantial protection (Fig. 5).

Additional confirmation of the importance of mitochondrial respiration in sensitizing $C$. albicans to HNP-1 was provided by experiments with proton ionophores. Addition of 50 $\mu \mathrm{M}$ carbonyl cyanide $m$-chlorophenylhydrazone (CCCP), a classical uncoupler of mitochondrial respiration, afforded virtually complete protection to $C$. albicans that had been exposed to $50 \mu \mathrm{g} / \mathrm{ml}$ of HNP-1 for $2 \mathrm{~h}$ (Fig. 6b). Another such mitochondrial inhibitor, 2,4-dinitrophenol, also completely protected the $C$. albicans, although 100 -fold higher concentrations $(5 \mathrm{mM})$ were required to obtain complete protection. None of the mitochondrial inhibitors, when tested at the aforementioned concentrations, impaired viability of control candida cells (data not shown). Given these indications that endogenous mitochondrial respiration sensitized $C$. albicans to HNP-1, it was not surprising to observe that anaerobic conditions virtually abolished the candidacidal activity of HNP-1 (Fig. 7).

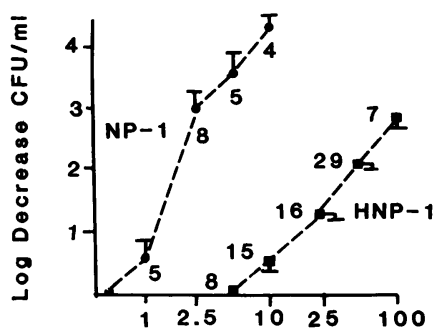

Defensin Concentration ( $\mu g / \mathrm{ml})$
Figure 2. Candidacidal activity of human and rabbit defensins. Blastoconidia, $1 \times 10^{6}$ $\mathrm{CFU} / \mathrm{ml}$, were incubated for 2 $\mathrm{h}$ at $37^{\circ} \mathrm{C}$ with the indicated concentrations of NP-1 (rabbit) or HNP-1 (human). The symbols represent mean reductions $\left(\log _{10} \mathrm{CFU} / \mathrm{ml}\right)$ from initial colony counts, and the vertical bars represent 1 SEM. The numbers alongside the data points indicate the number of experimental determinations at that concentration. 


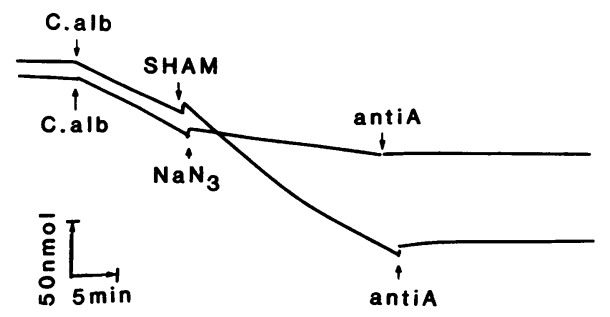

Figure 3. Effect of inhibitors on oxygen consumption. Oxygen electrode chambers contained $10 \mathrm{mM}$ sodium phosphate buffer at $37^{\circ} \mathrm{C}$ At the left arrows, $C$. albicans was added to achieve a final concentration of $5 \times 10^{6} / \mathrm{ml}$. At the middle arrows, either $3 \mathrm{mM} \mathrm{SHAM}$ or $5 \mathrm{mM} \mathrm{NaN}_{3}$ was added. At the right arrows, both chambers received $1 \times 10^{-6} \mathrm{M}$ antimycin A (antiA).

Comparative effects of inhibitors on HNP-1 and NP-1. Having demonstrated that susceptibility of $C$. albicans to HNP-1 is modified by the metabolic status of the target cell, we wondered if this would also be true for the more cationic rabbit macrophage and granulocyte defensin, NP-1. To compensate for the greater molar potency of NP-1 against $C$. albicans, we used equipotent rather than equimolar concentrations of NP-1 and HNP-1 in these studies.

We found that azide, antimycin A + SHAM, or CCCP had little inhibitory effect on susceptibility of $C$. albicans to NP-1, and that anerobic conditions provided only modest protection (Fig. 8).

Other cationic peptides. In addition to testing HNP-1 and $\mathrm{NP}-1$, we examined the effects of metabolic inhibitors on the candidacidal activities of mellitin, protamine, poly-L-lysine and poly-L-arginine. The potencies of these four polycations against $C$. albicans under our test conditions were intermediate between those of NP-1 and HNP-1 (data not shown). Once threshhold concentrations were exceeded, subsequent $\log _{10}$ reduction in CFU/ml was roughly linear functions of $\log _{10}$ peptide concentration. We selected concentrations that were approximately equipotent in candidacidal activity to 50 $\mu \mathrm{g} / \mathrm{ml} \mathrm{HNP}-1$.

The results of these experiments more closely resembled our findings with NP-1 than HNP-1 (Table II). With but a single exception, protamine, the candidacidal activity of the four "model" cationic peptides was not significantly inhibited by $\mathrm{CCCP}$, sodium azide, antimycin A + SHAM, or anaerobiosis.

Effects of divalent cations. We previously reported that the candidacidal activity of NP-1, the most potent rabbit PMN

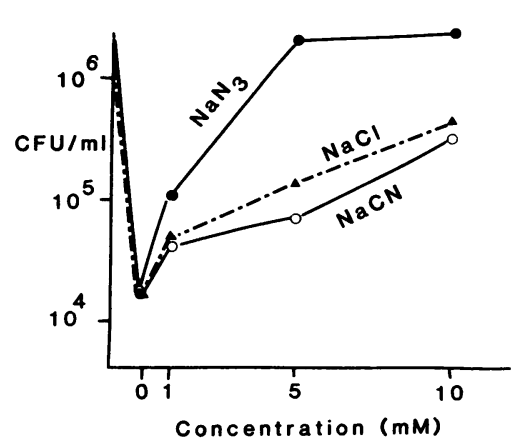

Figure 4. Effects of cyanide and azide. $C$. albicans was incubated at $37^{\circ} \mathrm{C}$ for $2 \mathrm{~h}$ with 50 $\mu \mathrm{g} / \mathrm{ml}$ of $\mathrm{HNP}-1$ in 10 mM sodium phosphate buffer that had been supplemented with the indicated concentrations of $\mathrm{NaCl}, \mathrm{NaCN}$, or $\mathrm{NaN}_{3}$. The input $\mathrm{CFU} / \mathrm{ml}$ are shown on the $y$-axis.

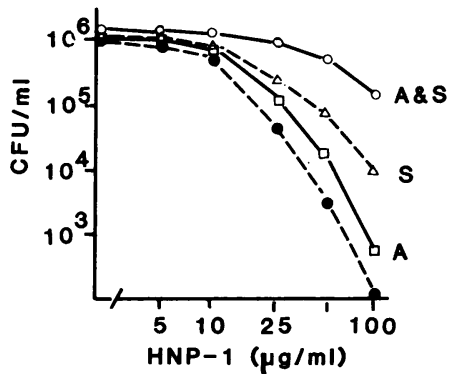

Figure 5. Effects of antimycin A and SHAM. C. albicans was incubated at $37^{\circ} \mathrm{C}$ for $2 \mathrm{~h}$ with $50 \mu \mathrm{g} / \mathrm{ml}$ of HNP-1 in $10 \mathrm{mM}$ sodium phosphate buffer that had been supplemented with (ㅁ) $1 \mu \mathrm{M}$ antimycin $\mathrm{A}(A)$, $(\Delta) 3$ mM SHAM $(S)$, or (O) a combination of the two $(A \& S)$. (•) Organisms incubated with HNP-1 in unsupplemented buffer.

defensin, was substantially inhibited by $\mathrm{Ca}^{2+}$ but not by $\mathrm{Mg}^{2+}$ (6). In contrast, both cations inhibited the candidacidal activity of HNP-1, although $\mathrm{Ca}^{2+}$ was somewhat more effective in this regard (Fig. 9). As little as $0.25 \mathrm{mM} \mathrm{Ca}^{2+}$ afforded virtually complete protection to $C$. albicans exposed to $50 \mu \mathrm{g} / \mathrm{ml}$ of HNP-1 for $2 \mathrm{~h}$ (data not shown). Not only did $\mathrm{Ca}^{2+}$ prevent candidacidal activity mediated by HNP-1 when present at the incubation's outset, its addition to an ongoing reaction terminated the otherwise progressive loss of Candida viability (Fig. 10).

Because $\mathrm{Fe}^{2+}$ has been reported to inhibit the ability of partially purified rabbit granulocyte cationic peptides to kill staphylococci (10), we examined the effects of this cation on candidacidal activity. Although $50 \mu \mathrm{M} \mathrm{Fe}^{2+}$ inhibited the candidacidal activity of NP-1 (Table III), it had no inhibitory effect on HNP-1. Even 10-fold higher concentrations of $\mathrm{Fe}^{2+}$ $(500 \mu \mathrm{M})$ were ineffective in this regard (data not shown).

Like HNP-1, NP-1 was very susceptible to inhibition by $\mathrm{Ca}^{2+}$, as previously reported (7). The candidacidal activities of mellitin and polylysine were also somewhat susceptible to inhibition by $\mathrm{Ca}^{2+}$. However, neither NP-1 nor any of the four model cationic proteins was affected by $\mathrm{Mg}^{2+}$. Conversely, although $\mathrm{Fe}^{2+}$ did not inhibit the activity of HNP-1, it decreased

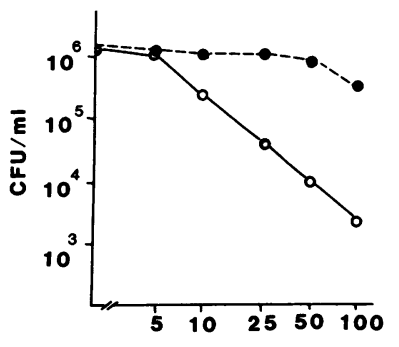

HNP- 1 CONCENTRATION $(\mu g / m I)$

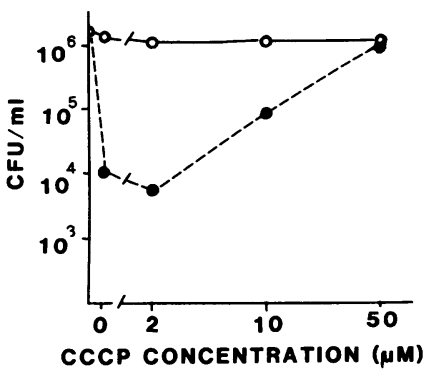

Figure 6. Effects of CCCP. (Upper) The solid circles represent $C$. albicans that had been $50 \mu \mathrm{g} / \mathrm{ml}$ of HNP-1 in $10 \mathrm{mM}$ sodium phosphate buffer containing the indicated concentrations of CCCP. The open circles show $C$. albicans that had been incubated with CCCP only. (Lower) C. albicans was incubated with various concentrations of HNP-1 in the presence (solid circles) or absence (open circles) of 50 $\mu \mathrm{M}$ CCCP. incubated at $37^{\circ} \mathrm{C}$ for $2 \mathrm{~h}$ with 


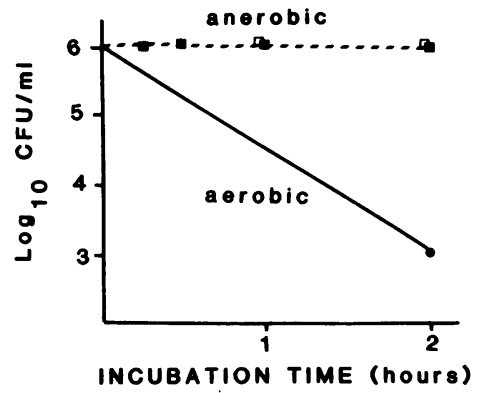

Figure 7. Effect of anerobic conditions. $C$. albicans was incubated for $2 \mathrm{~h}$ at $37^{\circ} \mathrm{C}$ with $50 \mu \mathrm{g} / \mathrm{ml} \mathrm{HNP}-1$ in 10 mM sodium phosphate buffer under aerobic $(\bullet)$ or anaerobic ( $\bullet$ ) conditions.

The anerobic control, incubated in buffer without HNP-1 is also shown (ם).

candidacidal activity by NP-1 and each of the four model proteins (Table III).

\section{Discussion}

PMN possess two principal means of killing microorganisms. One of these, often referred to as "oxygen-dependent," depends on production of reactive oxygen derivatives, including $\mathrm{O}_{2}^{-}, \mathrm{H}_{2} \mathrm{O}_{2}$, hydroxyl radical, hypochlorous acid, and reactive chloramines $(11,12)$. The other relies on delivery of PMN granule contents into phagocytic vacuoles $(13,14)$. Among the microbicidal components of PMN cytoplasmic granules are B/PI (13), cathepsin G $(15,16)$, muramidase (17), and defensins (4).

Because cationic proteins from diverse sources kill C. albicans and other microorganisms in vitro (18-23), our demon-

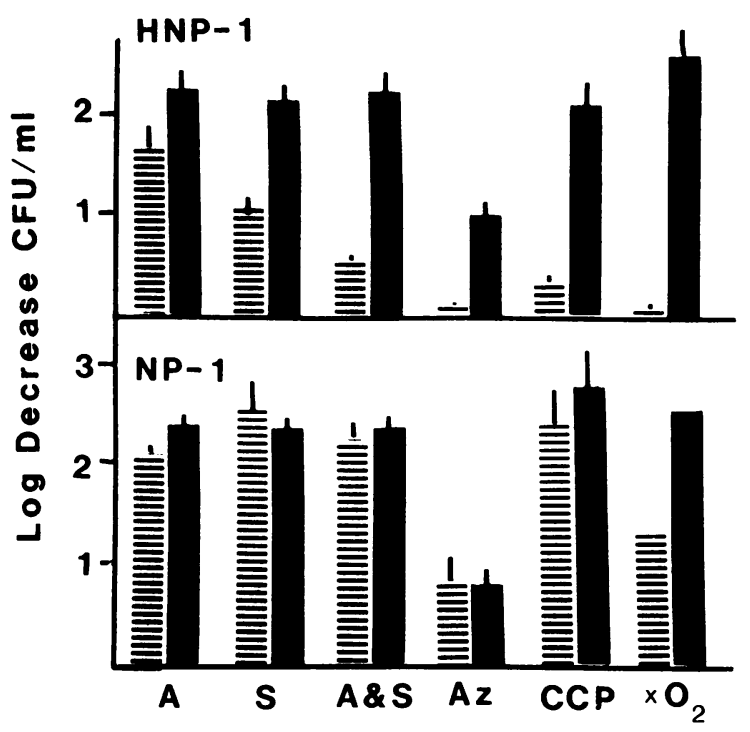

Figure 8. Effects of inhibitors on HNP-1 and NP-1. C. albicans was incubated for $2 \mathrm{~h}$ with HNP-1 $(50 \mu \mathrm{g} / \mathrm{ml})$ or NP-1 $(2.5 \mu \mathrm{g} / \mathrm{ml})$ in 10 mM sodium phosphate buffer in the absence (solid bars) or presence (striped bars) of the following inhibitors: $1 \mu \mathrm{M}$ antimycin $\mathrm{A}(A), 3$ mM SHAM $(S)$, a combination of the two $(A \& S), 5 \mathrm{mM} \mathrm{NaN}_{3}$ $(A z), 1 \mu \mathrm{M}$ CCCP (CCCP). Anerobic incubations are denoted by $\times \mathrm{O}_{2}$. Bars represent mean $+1 \mathrm{SEM} \log _{10}$ decrease in $\mathrm{CFU} / \mathrm{ml}$, derived from three to six separate experiments, except for anerobic studies with NP-1, which was a single experiment. The azide controls were supplemented with $5 \mathrm{mM} \mathrm{NaCl}$ to compensate for the effects of the $5 \mathrm{mM}$ azide on ionic strength (see also Fig. 4). stration that purified human defensins kill $C$. albicans blastoconidia in vitro does not establish that defensins show similar activity in phagocytic human neutrophils. However, earlier studies of the candidacidal mechanisms of human neutrophils, delineated two distinct candidacidal mechanisms. One of these was myeloperoxidase dependent (24), whereas the other functioned in myeloperoxidase-deficient and chronic granulomatous disease neutrophils (25). Although we have reported that human neutrophils kill ingested $C$. albicans blastoconidia primarily via myeloperoxidase-dependent processes (24), it should be noted that these experiments were performed with stationary-phase, 3-7-d-old yeast cultures. Organisms derived from such cultures are relatively inactive metabolically and are more resistant to rabbit (6) and human defensins than the 18-h-old cultures used in the present study.

Cathepsin G, a chymotrypsin-like cationic protein of the human neutrophil's azurophil granules, was previously identified as a potential effector of this reactive oxygen derivative-independent, second candidacidal mechanism $(26,27)$. The present studies suggest that the human neutrophil's defensins, HNP-1 and HNP-2, may be another. The recent observation that neutrophils from patients with Chediak-Higashi syndrome and "specific granule deficiency" lack cathepsin G and defensins, respectively, may facilitate an assessment of the specific antimicrobial roles of these granule components (28).

There may be functional consequences of our observation that HNP-1's ability to kill $C$. albicans was impaired by relatively low concentrations of divalent cations. We recently reported that $\sim 40 \%$ of $C$. albicans ingested by human PMN are located in phagocytic vacuoles that are imperfectly sequestered from the extracellular milieu and that such blastoconidia were killed much less effectively than those sequestered within fully sealed phagolysosomes (29). Since unsealed vacuoles are in communication with a high $\mathrm{Ca}^{2+} / \mathrm{Mg}^{2+}$ space (extracellular fluid), these divalent cations may protect $C$. albicans within unsealed vacuoles from defensin-mediated candidacidal activity. Although the concentration of $\mathrm{Ca}^{2+}$ in the phagolysosomes of human and murine macrophages was recently reported (30) to be quite low $(<100 \mu \mathrm{M})$, neither the $\mathrm{Ca}^{2+}$ nor the $\mathrm{Mg}^{2+}$ concentration of sealed neutrophil phagolysosomes has yet been measured.

A striking finding of the present study was that active mitochondrial metabolism by the target cell was necessary to sensitize $C$. albicans blastoconidia to the lethal effects of HNP-1. In contrast, we found no such requirement for several other cationic peptides, including the rabbit defensin NP-1, mellitin, polylysine, and polyarginine. Modulation of cationic protein-mediated candidacidal activity by target cell metabolism was observed by Olson et al. (20) who exposed C. albicans cells to several positively charged proteins, including protamine, lysozyme, and cytochrome $c$. Under their test conditions, several inhibitors of mitochondrial metabolism (azide, salicylanilide, 2,4-dinitrophenol) partially protected the target cells from the lethal effects of the proteins and respiration-impaired mutant strains showed less susceptibility than their wild-type progenitors. Although our experimental conditions were quite different from those employed by Olson et al., we also found that mitochondrial metabolism sensitizes $C$. albicans to the cytotoxic effects of protamine. It has also been reported that lysozyme can kill C. albicans in hypotonic solutions that contain small amounts of glucose (31) or other nu- 
Table II. Effect of Inhibitors on Candidacidal Activity

\begin{tabular}{lccccrc}
\hline \multicolumn{1}{c}{ Agent concn. } & $\begin{array}{c}\mathrm{HNP}-1 \\
50 \mu \mathrm{g} / \mathrm{ml}\end{array}$ & $\begin{array}{c}\mathrm{NP}-1 \\
2.5 \mu \mathrm{g} / \mathrm{ml}\end{array}$ & $\begin{array}{c}\text { Polylysine } \\
7.5 \mu \mathrm{g} / \mathrm{ml}\end{array}$ & $\begin{array}{c}\text { Polyarginine } \\
5.0 \mu \mathrm{g} / \mathrm{ml}\end{array}$ & $\begin{array}{c}\text { Protamine } \\
3.8 \mu \mathrm{\mu} / \mathrm{ml}\end{array}$ & $\begin{array}{c}\text { Mellitin } \\
5.0 \mu \mathrm{g} / \mathrm{ml}\end{array}$ \\
\hline $\mathrm{NaN}_{3}, 5 \mathrm{mM}$ & $0.13 \pm 0.11^{*}$ & $0.99 \pm 0.18$ & $0.72 \pm 0.12$ & $0.93 \pm 0.15$ & $0.17 \pm 0.01$ \\
Antimycin, $1 \mu \mathrm{M}$ & $0.77 \pm 0.06$ & $0.86 \pm 0.02$ & $0.59 \pm 0.23$ & $1.03 \pm 0.12$ & 0.96 \\
SHAM, $3 \mathrm{mM}$ & $0.52 \pm 0.04$ & $1.09 \pm 0.13$ & $0.81 \pm 0.11$ & $0.80 \pm 0.00$ & $0.95 \pm 0.02$ & $1.78 \pm 0.37$ \\
Antimycin + SHAM & $0.23 \pm 0.04$ & $0.92 \pm 0.02$ & $0.74 \pm 0.22$ & $0.78 \pm 0.06$ & $0.57 \pm 0.04$ & $1.00 \pm 0.23$ \\
CCCP, $50 \mu \mathrm{M}$ & $0.16 \pm 0.05$ & $0.83 \pm 0.03$ & $0.93 \pm 0.05$ & $0.96 \pm 0.02$ & $0.52 \pm 0.09$ \\
Anaerobiosis & $0.04 \pm 0.02$ & 0.53 & 1.17 & 1.21 & 0.35 & $1.74 \pm 0.14$ \\
& & & & & 0.88 \\
\hline
\end{tabular}

C. albicans was incubated for $2 \mathrm{~h}$ at $37^{\circ} \mathrm{C}$ in $10 \mathrm{mM}$ sodium phosphate buffer, $\mathrm{pH} 7.4$, with inhibitors and peptides as shown above. Control incubations for azide were supplemented with $5 \mathrm{mM} \mathrm{NaCl}$, to equalize ionic strengths. The controls for CCCP and antimycin A + SHAM contained ethanol ( $1 \% \mathrm{vol} / \mathrm{vol})$, as did mixtures containing these inhibitors. An "index of inhibition" was derived by dividing the $\log _{10} \mathrm{CFU}$ reduction in the presence of the inhibitor by the $\log _{10}$ CFU reduction observed in its absence (control). By this convention, an index of 0 denotes complete inhibition of peptide-mediated candidacidal activity, and an index of 1 denotes complete lack of inhibition. ${ }^{*}$ Index of inhibition, mean \pm SEM, $n=2-6$ (usually 3 or 4 ), except for anaerobic experiments and protamine + antimycin A, which were single experiments. Additional information about control values is provided in the legend to Table III.

trients (32), perhaps indicating a requirement for active target-cell metabolism under these conditions as well.

We cannot yet explain why active mitochondrial metabolism by the target cell is prerequisite for HNP-mediated candidacidal activity. It may be that energy-dependent uptake of HNP-1 by the target cells is required to allow the defensin-mediated candidacidal event(s) to occur. $C$. albicans can transport di- and tri- peptides via one or more energy-dependent oligopeptide permeases (33) and another yeast, $S$. cerevisiae, assimilates tetra and pentapeptides via similar systems (34). Activity of the $C$. albicans oligopeptide permease is completely inhibited by CCCP and azide (34), both of which also inhibit HNP-mediated candidacidal activity. However, HNP-1 contains 30 amino acid residues and the ability of oligopeptide permeases to transport such large peptides is unknown.

Inability of oligopeptide permeases to transport defensins need not preclude defensin entry into yeast cells. Various cat-

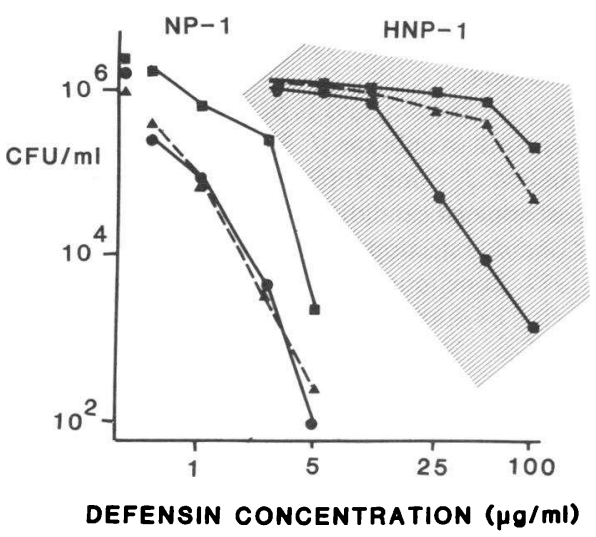

Figure 9. Effects of calcium and magnesium ions. C. albicans was incubated for $2 \mathrm{~h}$ at $37^{\circ} \mathrm{C}$ in $10 \mathrm{mM}$ sodium phosphate buffer that contained $0.5-5 \mu \mathrm{g} / \mathrm{ml}$ of NP-1 (unshaded area) or $5-100 \mu \mathrm{g} / \mathrm{ml}$ of HNP-1 (shaded area). The assays were conducted in unsupplemented buffer $(\bullet)$ or buffer that contained $0.5 \mathrm{mM} \mathrm{Ca}^{2+}(\boldsymbol{(})$ or 0.5 $\mathrm{mM} \mathrm{Mg}{ }^{2+}(\mathbf{\Delta})$. ionic proteins even larger than defensins (e.g., ribonuclease and cytochrome $c$ ) have been shown to penetrate $C$. utilis and $S$. cerevisiae yeast cells (21-23). Seminalplasmin (mol wt 6,385 ) can enter $C$. albicans $(35)$ as well as $S$. cerevisiae.

Entry of such large peptides into yeast cells may appear inconsistent with the conclusion, gained from studies of yeast cell wall porosity to polyethylene glycols of graded sizes (36, 37 ), that molecules whose Einstein-Stokes hydrodynamic radius corresponds to a mol wt $>620$ are not freely penetrable. However, the polyethylene glycol method neither excludes the presence of a subset of larger pores (28) nor predicts the behavior of charged molecules, such as defensins.

We suspect that the inability of HNP-3 to kill $C$. albicans and the requirement for active mitochondrial metabolism on the part of the target cell to sensitize it to HNP-1 or 2 may be integrally related. The presence of a negatively-charged aspartic acid residue in HNP-3 (37) alters the amino-terminus and renders the peptide less cationic (net charge $=+2$ ) than its congeners, HNP-1 or -2 (net charge $=+3$ ). We speculate that defensin-mediated candidacidal activity may depend on interactions between the positively charged defensin molecules and the yeast cell's plasma membrane that are influenced by the

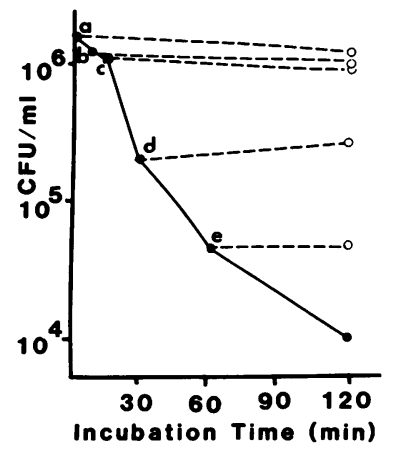

Figure 10. Delayed addition of calcium ions. $C$. albicans was incubated for $2 \mathrm{~h}$ with $50 \mu \mathrm{g} / \mathrm{ml}$ of HNP-1 in $10 \mathrm{mM}$ sodium phosphate buffer (o). At the outset of the incubation $(a)$ or after $7.5(b)$, $15(c), 30(d)$, and $60(e) \mathrm{min}$ of incubation with HNP-1 under $\mathrm{Ca}^{2+}$-free conditions, $\mathrm{Ca}^{2+}$ (final concentration, $0.5 \mathrm{mM}$ ) was added to selected incubation mixtures, whose surviving CFU were determined after a total incubation time (before and after addition of $\left.\mathrm{Ca}^{2+}\right)$ of $120 \mathrm{~min}$. $(---0)$ Samples plated after delayed $\mathrm{Ca}^{2+}$ addition. 
Table III. Effect of Divalent Cations on Candidacidal Activity

\begin{tabular}{lccccrr}
\hline Agent concn. & $\begin{array}{c}\mathrm{HNP}-1 \\
50 \mu \mathrm{g} / \mathrm{ml}\end{array}$ & $\begin{array}{c}\mathrm{NP}-1 \\
2.5 \mu \mathrm{g} / \mathrm{ml}\end{array}$ & $\begin{array}{c}\text { Polylysine } \\
7.5 \mu \mathrm{g} / \mathrm{ml}\end{array}$ & $\begin{array}{c}\text { Polyarg. } \\
5.0 \mu \mathrm{g} / \mathrm{ml}\end{array}$ & $\begin{array}{c}\text { Protamine } \\
3.8 \mu \mathrm{g} / \mathrm{ml}\end{array}$ & $\begin{array}{c}\text { Mellitin } \\
5.0 \mu \mathrm{g} / \mathrm{ml}\end{array}$ \\
\hline $\mathrm{Ca}^{2+}, 0.5 \mathrm{mM}$ & $0.05 \pm 0.03$ & $0.27 \pm 0.09$ & $0.43 \pm 0.15$ & $0.94 \pm 0.09$ & $0.73 \pm 0.15$ \\
$\mathrm{Mg}^{2+}, 2 \mathrm{mM}$ & $0.16 \pm 0.07$ & $0.98 \pm 0.13$ & $1.04 \pm 0.03$ & $0.90 \pm 0.09$ & $1.05 \pm 0.08$ & $0.31 \pm 0.12$ \\
$\mathrm{Fe}^{2+}, 50 \mu \mathrm{M}$ & $1.30 \pm 0.11$ & $0.29 \pm 0.07$ & $0.49 \pm 0.19$ & $0.33 \pm 0.21$ & $0.07 \pm 0.04$ & $0.07 \pm 0.03$
\end{tabular}

The incubation conditions and calculations used to derive an "index of inhibition" are as described in the legend to Table II. Data represent mean \pm SEM, $n=3$. The $\log _{10}$ reductions [mean \pm SEM, $(n)$ ] in CFU/ml caused by the indicated concentrations of peptide in buffers lacking added inhibitors or divalent cations were: HNP-1, $2.07 \pm 0.05$ (29); NP-1, $2.64 \pm 0.16$ (11); polylysine, $2.49 \pm 0.21$ (12); polyarginine, $2.02 \pm 0.29$ (12); protamine, $2.15 \pm 0.19$ (10); and mellitin, $1.82 \pm 0.26$ (11).

membrane's electrochemical potential. If this is correct, then factors that affect the local or net positive charge of defensins or that diminish the membrane's electronegative (inside) potential could reduce the cytotoxic consequences of defensinyeast cell interaction. We plan to examine such possibilities in future experiments.

\section{Acknowledgments}

We thank Sylvia S. S. L. Harwig for excellent assistance in the purification of defensins.

These studies were supported, in part, by grants from the National Institutes of Health-AI-22839 and AI-16252 (Dr. Lehrer), AI-22931 (Dr. Selsted), AI-21931 and HL-35640 (Dr. Ganz) and by grant ONRN00014-86-K-0525 from the Office of Naval Research (Dr. Selsted).

\section{References}

1. Selsted, M. E., S. S. L. Harwig, T. Ganz, J. W. Schilling, and R. I. Lehrer. 1985. Primary structures of three human neutrophil defensins. J. Clin. Invest. 76:1436-1439.

2. Rice, W. G., T. Ganz, J. M. Kinkade, Jr., M. E. Selsted, R. I. Lehrer, and R. T. Parmley. 1987. Defensin-rich dense granules of human neutrophils. Blood. 70:757-765.

3. Ganz, T., M. E. Selsted, D. Szklarek, S. S. L. Harwig, K. Daher, D. F. Bainton, and R. I. Lehrer. 1985. Defensins, natural peptide antibiotics of human neutrophils. J. Clin. Invest. 76:1427-1435.

4. Daher, K. A., M. E. Selsted, and R. I. Lehrer. 1986. Direct inactivation of viruses by human granulocyte defensins. J. Virol. 1068-1974.

5. Selsted, M. E., D. Szklarek, and R. I. Lehrer. 1984. Purification and antibacterial activity of antimicrobial peptides of rabbit granulocytes. Infect. Immun. 45:150-154.

6. Selsted, M. E., D. Szklarek, T. Ganz, and R. I. Lehrer. 1985. Activity of rabbit leukocyte peptides against Candida albicans. Infect. Immun. 49:202-206.

7. Selsted, M. E., D. M. Brown, R. J. DeLange, S. S. L. Harwig, and R. I. Lehrer. 1985. Primary structures of six antimicrobial peptides of rabbit peritoneal neutrophils. J. Biol. Chem. 260:4579-4584.

8. Henry, M.-F., and E.-J. Nyns. 1975. Cyanide-insensitive respiration. An alternative mitochondrial pathway. Subcell Biochem. 4:1-65.

9. Shepard, M. G., C. M. Chin, and P. A. Sullivan. 1978. The alternate respiratory pathway of Candida albicans. Arch. Microbiol. 116:61-67.

10. Gladstone, G. P., and E. Walton. 1970. Effect of iron on the bactericidal proteins from rabbit polymorphonuclear leucocytes. $\mathrm{Na}$ ture (Lond.). 227:849-851.

11. Babior, B. M. 1984. Oxidants from phagocytes: agents of defense and destruction. Blood. 64:959-966.
12. Grisham, M. B., M. M. Jefferson, D. F. Melton, and E. L. Thomas. 1984. Chlorination of endogenous amines by isolated neutrophils. J. Biol. Chem. 259:10404-10413.

13. Elsbach, P., and J. Weiss. 1985. Oxygen-dependent and oxygen-independent mechanisms of microbicidal activity of neutrophils. Immunol. Lett. 11:159-163.

14. Spitznagel, J. K. 1984. Nonoxidative antimicrobial reactions of leukocytes. Contemp. Top. Immunobiol. 14:283-343.

15. Odeberg, H., and I. Olsson. 1975. Antibacterial activity of cationic proteins from human granulocytes. J. Clin. Invest. 56:11181124.

16. Odeberg, H., and I. Olsson. 1975. Mechanisms for the microbicidal activity of cationic proteins of human granulocytes. Infect. Immun. 14:1269-1275.

17. Klebanoff, S. J., and R. A. Clark. 1978. The Neutrophil: Function and Clinical Disorders. North Holland Publishing Company, Amsterdam. pp. 451-453.

18. Miller, B. F., R. Abrams, A. Dorfman, and M. Klein. 1942. Antibacterial properties of protamine. Science (Wash. DC). 96:428430.

19. Sela, M., and E. Katchalski. 1959. Biological properties of poly-alpha-amino acids. Adv. Protein Chem. 14:391-477.

20. Olson, V. L., R. L. Hansing, and D. O. McClary. 1977. The role of metabolic energy in the lethal action of basic proteins on Candida albicans. Can J. Microbiol. 23:166-174.

21. Schlenk, F., and J. L. Dainko. 1965. Action of ribonuclease preparations on viable yeast cells and spheroplasts. J. Bacteriol. 89:428-436.

22. Svihla, G., J. L. Dainko, and F. Schlenk. 1969. Ultraviolet micrography of penetration of exogenous cytochrome $C$ into the yeast cell. J. Bacteriol. 100:498-504.

23. Yphantis, D. A., J. L. Dainko, and F. Schlenk. 1967. Effect of some proteins on the yeast cell membrane. J. Bacteriol. 94:1509-1515.

24. Lehrer, R. I., and M. J. Cline. 1969. Leukocyte myeloperoxidase deficiency and disseminated candidiasis: the role of myeloperoxidase in resistance to Candida infection. J. Clin. Invest. 48:1478-1487.

25. Lehrer, R. I. 1972. Functional aspects of a second mechanism of candidacidal activity by human neutrophils. J. Clin. Invest. $51: 2566-2572$.

26. Lehrer, R. I., K. M. Ladra, and R. B. Hake. 1975. Nonoxidative fungicidal mechanisms of mammalian granulocytes: demonstration of components with candidacidal activity in human, rabbit and guinea pig leukocytes. Infect. Immun. 11:1226-1234.

27. Drazin, R. E., and R. I. Lehrer. 1977. Fungicidal properties of a chymotrypsin-like cationic protein from human neutrophils: adsorption to Candida parapsilosis. Infect. Immun. 17:382-388.

28. Ganz, T., J. A. Metcalf, J. I. Gallin, and R. I. Lehrer. 1987. Two genetic disorders that affect human neutrophils are associated with deficiencies of microbicidal and cytotoxic granule proteins. Clin. Res. 35:424A. (Abstr.) 
29. Cech, P., and R. I. Lehrer. 1984. Heterogeneity of human neutrophil phagolysosomes: functional consequences for candidacidal activity. Blood. 64:147-151.

30. Pollack, C., S. C. Straley, and M. S. Klempner. 1986. Probing the phagolysosomal environment of human macrophages with a $\mathrm{Ca}^{2+}$-responsive operon fusion in Yersinia pestis. Nature (Lond.). 322:834-836.

31. Kamaya, T. 1970. Lytic action of lysozyme on Candida albicans. Mycopathol. Mycol. Appl. 42:197-207.

32. Marquis, G., S. Montplaisir, S. Garzon, H. Strykowski, and P. Auger. 1982. Fungitoxicity of muramidase: ultrastructural damage to Candida albicans. Lab. Invest. 46:627-636.

33. Davies, M. B. 1980. Peptide uptake in Candida albicans. J. Gen. Microbiol. 121:181-186.

34. Naider, F., J. M. Becker, and E. Katzir-Katchalski. 1974. Utilization of methionine-containing peptides and their derivatives by a methionine-requiring auxotroph of Saccharomyces cerevisiae. J. Biol. Chem. 249:9-20.

35. Scheit, K. H., and P. M. Bhargava. 1985. Effect of seminalplasmin, an antimicrobial protein from bull semen, on growth and macromolecular synthesis in Candida albicans. Ind. J. Biochem. Biophys. 22:1-7.

36. Cope, J. E. 1980. The porosity of the cell wall of Candida albicans. J. Gen. Microbiol. 119:253-255.

37. Scherrer, R., L. Louden, and P. Gerhardt. 1974. Porosity of the yeast cell wall and membrane. J. Bacteriol. 118:534-540.

38. Haberman, E., and J. Jentsch. 1967. Sequenz analys sed Mellitins aus den tryptischen und peptischen Spaltstucken. Hoppe-Seyler's Z. Physiol. Chem. 348:37-50.

39. Dayhoff, M. O. 1972. Atlas of Protein Sequence and Structure. Volume 5: D-278. National Biomedical Research Foundation, Georgetown University Medical Center, Washington, D.C. 